DOI: 10.1515/pof-2016-0011

VOLUME 8, ISSUE 2, 2016

ISSN: 2036-5438

\title{
EU governance in the run-up to 2025: A Joint Budgetary Procedure
}

by

Francesco Nicoli*

Perspectives on Federalism, Vol. 8, issue 2, 2016 


\begin{abstract}
The Euro Area (Eurozone, or EZ) is navigating uncharted waters; it has started, in slow motion, to slide towards a fiscal federation, while still lacking both the fiscal capacity and the democratic qualification to achieve this goal. Strengthening the EMU's democratic profile is a fundamental requirement for the sustainability of the EMU as much as its completion with a fiscal and economic arm. Yet, according to the Five Presidents Report released in 2015, no substantial progress is expected to be achieved before 2025. Against this background, this paper is structured in two parts. The first part analyses the most recent trends in the Governance of the Eurozone. The second part discusses whether a transition from governance to government of the Monetary Union is both feasible and effective, advancing a new proposal -a Joint Budgetary Procedure- tailored to strengthen the European Semester with stronger incentive mechanisms, greater reach and stronger governance.
\end{abstract}

Key-words

Eurozone, Economic and Monetary Union, Joint Budgetary Procedure 


\section{Introduction}

The Euro Area is navigating uncharted waters; it has begun, in slow motion, to slide towards a fiscal federation. However, it currently lacks both the fiscal capacity and the democratic qualification to achieve this goal. Politicisation and democratisation are fundamental requirements for the sustainability of the EMU as much as its completion with a fiscal and economic arm. The weak point of the EMU has been known since before its inception; while the rationale for a monetary union fiscal capacity could be tracked back to Mundell's $(1960,1961)$ work on Optimal Currency Areas, whose common budget would allow several adjustment functions (De Grauwe, 2012), the actual strengthening of EU budgetary powers was proposed by McDougall (1977) who reported that a budget of 7\% of EU GDP would have been necessary to support the Monetary Union Plan presented by Werner (1971). ${ }^{\mathrm{I}}$ Yet, there is today little appetite in European Capitals for a further pooling of sovereignty and resources in the short run. Although "the long overhaul", recently agreed at the EU level, is still contested, the timeline proposed by the Five Presidents' Report in 2015 is realistic. Calls for a more politicised and legitimised economic governance have multiplied in the second half of 2015 (Zuleeg, 2015; Terzi, 2015). Yet, while the process of politicisation of EU public life and institutions has fascinated many scholars for many years, it provoked minimal excitement among the public at large until recent years. The crisis, however, has contributed to change this picture; from antiAusterity protesters to opportunistic politicians, Europe has witnessed a growing rhetoric against the "unelected bureaucrats" (courtesy of Nigel Farage, (2014)) taking decisions instead of the people. The academic politicisation debate has focused, over time, on two interdependent strands: the first concerns the changing role of the European Commission, while the second investigates the emergence of the European Parliament as key actor in EU policy making, bringing the traditional right/left divide in European politics.

In particular, Hix $(\underline{2011}, \underline{2013}, \underline{2014})$ has long supported the strengthening of the European Parliament's powers in order to foster politicisation and thus [mass] participation in EU governance. The lack of salience of European policy for mass-politics has been often referred to as one of the most worrying features of the EU, pushing some scholars 
like Viviane Schmidt (2006: 223) to argue that the EU is creating "policies without politics". A contrasting argument is made by Majone (1997) and Moravcsik (2002), who argue that as long as the EU deals primarily with non-redistributive policies, it does not need politicisation and can better pursue its goals, being kept "insulated" from party politics. However, Majone (2014) recognises that, in the wake of the crisis, integration of redistributive policies has taken place and thus politicisation should follow. A politicisation narrative has often been developed as a solution to the alleged "democratic deficit" of the European Union, which is discussed in detail by Nicoli (2015). In general, politicisation has been perceived as a consequence of ever-increasing powers of the European Union, resulting from both a bottom-up process (the electorate's change in attitudes "from permissive consensus to restrictive dissensus", as argued by Hooghe and Marks (2009)) and a top-down process, with an incremental self-understanding of the European Commission (and of its president) as the true executive power in the EU (Christiansen, 1997, 2001). The evolution of the constitutional base of the Union has followed these two trends, strengthening the autonomy and powers of the Commission on the one hand, and reinforcing the link between the Parliament and the European elections on the other. The role of the European Commission has always been stretched between two poles: on the one hand, the Commission was seen as "guardian of the Treaties", i.e. as the supranational enforcer of a multilaterally agreed, rule-based governance; on the other hand, the Commission is increasingly perceived as the "kingmaker" of the European political game, acting instead as the pivotal power in a supranational form of government (Zuleeg, 2015). Against this background, this paper is structured in two parts. The first part analyses the most recent trends in the Governance of the Eurozone, focusing, in particular, on the debate on fiscal rules. We then show that a transition from governance to government of the Monetary Union is both feasible and effective; finally the paper advances an alternative proposal to strengthen Economic Governance before 2025, a "Joint Budgetary Procedure" aiming to reinforce the European Semester with a fiscal pillar. 


\section{A governance under stress: trends and evolution}

\subsection{The governance as it stands today}

A working monetary Union needs three essential functions: a crisis-resolution mechanism, a shock-absorbing capacity, and a system of prevention of asymmetric shocks. In two fields substantial progress was achieved during the crisis: the strengthening of the fiscal pillar of economic policy coordination, and progress on crisis-resolution mechanisms. While progress on the creation of a "safety net" in case of crisis was substantially achieved thanks to the creation of the ESM in 2012 and to the factual change of stance of the ECB under the leadership of Mr. Draghi, the Union's capacity to shape a coordinated economic policy, to provide a joint budget, and to enact counter-cyclical expenditure is heavily underdeveloped. Even fiscal rules, as they are conceived today, are not perceived as optimal by member states. Their reform, however, is a major source of division among member states. The original set of fiscal rules of the EU is laid down in articles 121 and 128 of the TFEU and is operationalised by a protocol known as the Stability and Growth Pact (SGP), established in 1998 and reformed several times thereafter. It was originally organized on two well-known pillars (the "preventive" and "corrective" arms) with three goals: preventing excessive deficits, ensuring debt convergence, and ensuring medium-term deficit reduction. The SGP was first modified in 2005 after German and French failures to comply with deficit thresholds; to avoid sanctioning, a reform was introduced to grant greater autonomy to governments, and weaken the Commission's power of delivering sanctions. The SGP was modified again, this time in the opposite direction, in 2011, tightening the thresholds for Euro Area member states and introducing the Reversed Majority Voting principle on sanctions, granting to the Commission the automatic approval of decisions on sanctions unless member states in the Council succeed in forming an opposing majority. The SGP reform was accompanied by four other important measures in fiscal policy: the introduction (with the Six Pack), and subsequent reform (with the Two Pack) of fiscal monitoring and coordination; the introduction (with the Six Pack) of a common fiscal framework; and the approval of the Treaty on Stability, Coordination and Governance (TSCG, also known as Fiscal Compact) which requires the constitutionalisation in national basic laws of the fiscal rules introduced with the 2011 SGP reform. In sum, the period from 2010-2013 was characterized by intense reforms in the 
fiscal and economic framework of the Union, heading in the direction of more supervision, more control, and more sanctioning.

Since 2012 the EU has entered a phase of long-term overhaul of its governance framework. The Four Presidents' report, in December 2012 co-authored by Juncker (at the time President of the Eurogroup), Draghi, Van Rompuy and Barroso, set the governance agenda for the following years with the aim of addressing the missing features of Governance apparatus. For each timeframe a number of key policies were introduced. Table 1 recalls the priorities set by the report along with their timeframe and their actual status. Three years later, the EU is still far from completing the key policy actions included in the period 2013-2014, let alone past-2014. Moreover, the Five-Presidents' Report, published in 2015 and originally expected to provide guidance for the completion of the original plan, constituted in fact a decisive backtracking exercise. Several priority actions of primary importance have disappeared from the report, including the introduction of a shock-absorbing mechanism and the introduction of a system of contractual agreements. The creation of a European Treasury, which could, in theory, provide both cancelled functions, has been delayed to no sooner than 2025; the headline "political union and democratic legitimacy" has been shrunk, de facto, to a formal presentation of the Annual Growth Survey in front of the European Parliament and to the introduction of common representation in international economic institutions by 2025. None of the missing fundamental features (effective coordination to prevent rising asymmetries, shockabsorbing capacity) are to enter into force before 2025 .

Introduced in December 2011the European Semester is perceived as a weak juncture of governance. The European Semester inherited the practice of economic policy coordination applied in Europe since the Maastricht Treaty, in particular the "Broad Economic Policy Guidelines" and the "employment guidelines" (the main building blocks of the "open method of coordination[OMC]" introduced to achieve the goals of the Lisbon 2010 Agenda), the "national reform programmes" that member states had to deliver as a part of the OMC, and the "stability plans" delivered according with the Stability and Growth Pact (SGP) . 
Table 1

2012 Four Presidents' Report \& 2015 Five Presidents' Report Priorities compared

\begin{tabular}{|c|c|c|c|c|c|c|}
\hline \multicolumn{4}{|c|}{2012} & \multicolumn{3}{|c|}{2015} \\
\hline Period & key actions & \multicolumn{2}{|l|}{ Status } & Period & Key actions & Status \\
\hline \multirow{5}{*}{$\begin{array}{l}2012- \\
2013\end{array}$} & $\begin{array}{c}\text { completion and } \\
\text { implementation of Six } \\
\text { Pack, Two Pack, } \\
\text { Fiscal Compact }\end{array}$ & $\begin{array}{l}\text { approved by } \\
\text { March, } 2013\end{array}$ & in time & \multirow{3}{*}{$\begin{array}{l}\text { 2015- } \\
2017\end{array}$} & $\begin{array}{l}\text { Competitiveness } \\
\text { councils \& fiscal } \\
\text { council of the EZ }\end{array}$ & $\begin{array}{l}\text { EZ fiscal council introduced } \\
\text { in November 2015; } \\
\text { competitiveness Councils } \\
\text { recommended to the } \\
\text { Council in Nov. } 2015\end{array}$ \\
\hline & $\begin{array}{c}\text { creation of an ex-ante } \\
\text { coordination } \\
\text { mechanism for } \\
\text { structural reforms } \\
\end{array}$ & $\begin{array}{c}\text { Communication } \\
\text { in March 2013; } \\
\text { legal text never } \\
\text { proposed } \\
\end{array}$ & $\begin{array}{c}\text { not } \\
\text { approved }\end{array}$ & & $\begin{array}{l}\text { Common insurance } \\
\text { scheme; Capital } \\
\text { market union }\end{array}$ & $\begin{array}{c}\text { Common Insurance Scheme } \\
\text { to be presented by End } \\
2016^{*}\end{array}$ \\
\hline & $\begin{array}{l}\text { Banking Union: } \\
\text { Single Supervisory } \\
\text { Mechanism }\end{array}$ & $\begin{array}{c}\text { approved by } \\
\text { October 2013; } \\
\text { operational 2014 } \\
\text { Q4 }\end{array}$ & in time & & $\begin{array}{c}\text { Change of the } \\
\text { European Semester } \\
\text { structure \& increase } \\
\text { parliament's } \\
\text { involvement } \\
\end{array}$ & $\begin{array}{c}\text { Communication presented in } \\
\text { November } 2015\end{array}$ \\
\hline & $\begin{array}{l}\text { Framework for bank's } \\
\text { recapitalization } \\
\text { through ESM }\end{array}$ & $\begin{array}{c}\text { approved in } \\
\text { December } 2014\end{array}$ & $\begin{array}{l}\text { Delayed } \\
\text { approval }\end{array}$ & \multirow{6}{*}{$\begin{array}{l}2017- \\
2025\end{array}$} & $\begin{array}{c}\text { Binding } \\
\text { Macroeconomic } \\
\text { convergence } \\
\text { procedure }\end{array}$ & \multirow{4}{*}{$\begin{array}{l}\text { Details to be published in } \\
\text { the } 2017 \text { white paper }\end{array}$} \\
\hline & $\begin{array}{c}\text { Banking Union: } \\
\text { harmonization of } \\
\text { deposit guarantees }\end{array}$ & $\begin{array}{l}\text { approved in June } \\
2014\end{array}$ & $\begin{array}{l}\text { Delayed } \\
\text { approval }\end{array}$ & & $\begin{array}{l}\text { fiscal stabilisation } \\
\text { mechanism }\end{array}$ & \\
\hline \multirow[t]{2}{*}{$\begin{array}{l}2013- \\
2014\end{array}$} & $\begin{array}{l}\text { Banking Union: } \\
\text { Resolution authority }\end{array}$ & $\begin{array}{l}\text { Approved in July } \\
2014 \text {. Only } 2 \\
\text { ratifications of the } \\
\text { intergovernmental } \\
\text { agreement by } \\
\text { June } 2015 . \text { Once } \\
\text { approved, it will } \\
\text { be phased in } 10 \\
\text { years.* }\end{array}$ & $\begin{array}{l}\text { in time, } \\
\text { but slow } \\
\text { application }\end{array}$ & & Euro Area Treasury & \\
\hline & $\begin{array}{l}\text { Contractual } \\
\text { agreements }\end{array}$ & $\begin{array}{c}\text { Communication } \\
\text { in March 2013; } \\
\text { legal text never } \\
\text { proposed } \\
\end{array}$ & $\begin{array}{c}\text { not } \\
\text { approved }\end{array}$ & & ESM into EU Law & \\
\hline \multirow[t]{2}{*}{ 2014- } & $\begin{array}{l}\text { shocks- absorption } \\
\text { fiscal capacity } \\
\text { through } \\
\text { unemployment } \\
\text { insurance scheme } \\
\end{array}$ & $\begin{array}{l}\text { in-depth analysis } \\
\text { begun in } 2015\end{array}$ & Ongoing & & \multirow[t]{2}{*}{$\begin{array}{l}\text { Joint EZ } \\
\text { representation in } \\
\text { International } \\
\text { economic institutions }\end{array}$} & \multirow[t]{2}{*}{$\begin{array}{l}\text { Communication \& Proposal } \\
\text { for a council decision } \\
\text { presented in November } \\
2015\end{array}$} \\
\hline & political integration & $?$ & $?$ & & & \\
\hline
\end{tabular}

The 2011 reform integrated the guidelines into a single document of economic policy, the Annual Growth Survey (AGS) approved by the European Commission in October each year. By April, Member states have to submit their Stability Plans and National Reform Programmes presenting their actions to implement the AGS goals and the fulfillment of SGP obligations; by June each year, the Commission and the Council deliver 
a set of recommendations to member states concerning yearly priorities on their budgets and economic policy. In March 2013 the process was strengthened even further by adding supervision of the actual implementation in national budget plans of the commitments undertaken in the programmes submitted in April; by end of October member states must submit their draft budgetary laws for the following year, and the Commission is in charge of checking their compatibility with the recommendations delivered earlier in the year. These reforms notwithstanding, the Semester remains burdensome, and moreover is still ineffective (De Finance, 2014). There are currently only limited means available to induce a country to respect its own commitments; only the subset of recommendations concerning deficit and debt reduction (the fiscal rules discussed in the next section) can be enforced through the preventive and corrective arms of the SGP. The existence of macroeconomic imbalances could also be potentially sanctioned under the new Macroeconomic Imbalances Procedure introduced in 2011, but it has never been used so far and moreover its criteria do not constitute, di per se, a set of policies or economic measures. As a consequence, the $\mathrm{EU}$ is missing a form of instrument to deliver any incentives (both negative, as sanctions, and positive, like financial support) to ensure the implementation of structural reforms in countries in need of them. While the flexibility clause of the SGP introduced in January 2015 may provide some incentives, not all kinds of adjustments on the side of member states can be met by a simple relaxation of fiscal rules. Finally, the proposal to establish a contractual agreements mechanism was abandoned in 2014. The creation of such a system of contractual agreements had been discussed, under various labels, in each Head of States and Governments' meeting since June 2012. It constituted one of the three priorities of the Van Rompuy report endorsed by the European Council in December 2012 but disappeared in the 2015 update. A first proposal from the Commission (Communication $165 / 2013$ ) was put forward in March 2013. Later in the year, the contractual agreements mechanism became one of the cornerstones of the Franco-German bilateral agreement of May 21st, 2013. It was further discussed in the European Council meetings of June, October and December 2013. The last European Council of 2013 registered, for the first time, a preliminary agreement on the forms, functions and structure of the "partnerships for growth, jobs and competitiveness"- the final denomination of the contractual agreements mechanism in the EU's jargon. 
Finally, the last pillar of the genuine economic union agenda -constituted by a shockabsorbing fiscal capacity, notably through a European Unemployment Benefit Scheme (Beblavy and Maselli, 2015; Beblavy et al., 2015)- is in its early stages of exploration, and should not be expected to deliver actual results, let alone a legislative proposal, in the coming years. The Juncker Fund, which formally aims to foster growth through enhancing investment across the EU, appears to work -thanks to its flexibility clauses and to the exclusion of investment contributions from national deficits calculations- rather as a backdoor solution for the introduction of a golden rule rather than as a true fiscal stimulus initiative (for an in-depth discussion of the issue please refer to Nicoli 2016b). The construction of a genuine economic union, however, remains a medium and long term priority for the Euro Area. In this regard, the second part of this paper discusses two alternatives for an incremental process towards the 2025 deadline for the creation of a genuine economic union; a contractual agreements scheme and a joint budgetary procedure.

\subsection{Legitimacy and effectiveness shortcomings}

Whether the European Commission enjoys sufficient democratic legitimacy to implement strengthened Economic Governance is still an open question. Article 17.7 TEU, in the Treaty of Lisbon, introduced an electoral link between the Commission and the majority in the European Parliament. This has been reflected in an inter-institutional power game that led to the election of Mr. Juncker to the presidency of the Commission, thanks to an inter-party agreement establishing a de-facto Grand Coalition in the European Parliament, able to overcome Germany's scepticism and the UK's vetoes at the moment of the election. Although a Grand Coalition in the European Parliament is hardly news, the polarization of the Parliament has increased thanks to the growing success of Eurosceptic parties, which control- both in the soft ECR groups and in the extreme EFD and ENFaround $20 \%$ of the Chamber, and to the increased salience of integrationist-Eurosceptic dynamics in the Parliament during the crisis (Otjes and Van der Veer, 2016). Politically, a large minority has created the need for strengthened coordination between Juncker and his majority, who reportedly meet at least once a month (Palmeri 2015). However, such a coalition has no practical effectiveness outside the formal competences of the European Parliament, whose role in economic governance is so far extremely limited. Moreover it 
cannot hold decision making powers (and therefore veto powers) on joint economic policy (by necessity Europeanized) or offer a viable alternative, as exemplified by the Greek crisis of July 2015. As a matter of fact, it makes little difference if the veto is expressed by a government- as in classical intergovernmentalism- or by a parliament, as in the “interparliamentarism" theorized by Nicolaidis (2013) and Hefftler and Wessels (2013) and implemented in the Lisbon Treaty (art. 8 TEU) the TSCG (at. 13) and in the agreement for a new settlement for the UK (Tusk, 2016). Even its proponents realise it differs from democracy so that a new noun-demoi-cracy- had to be minted to mark the difference. Both interparliamentarism, as it is enacted in today's setting, and intergovernmentalism, require unanimous decision making on fiscal and economic policy, which is a violation of the fundamental principle of democratic decision making; majority voting (Nicoli 2016).

\section{From Governance to Government: an alternative path towards 2025}

The previous sections have shown that, despite the undeniable shortcomings of the Eurozone, the EU does have a map, a Captain and a schedule to navigate the uncharted waters of fiscal integration. Yet, while the suggested timeline might be realistic, it is surely overly cautious; for no change (other than cosmetic) is expected to be even discussed before spring 2017, when the Commission is to propose a white paper on the future of the Eurozone (COM 600/2015). Afterwards, negotiations for Treaty Change are set to begin after the German and French elections in 2018 with the new Treaty expected to enter into force by 2025. However, it is evident that this timeline implies no effective change until 2025: muddling through until 2017 and treaty negotiations thereafter. In other words, the existing budget of the EU, the Multiannual Financial Framework (MFF) is not expected to move beyond the $1 \%$ GDP threshold for the time being, remaining substantially below central governments' expenditure in existing fiscal federations (table 2) and thus unable to address the shortcomings of the EMU, which would require a minimum of a $2 \%$ EMU GDP dedicated budget. While there is no lack of proposals for reform, most existing plans to finalise EMU with fiscal powers (see Pisani-Ferry, Vihriälä and Wolff 2013 for a good summary) rely heavily on Treaty Change, which is not to be expected in the next ten years. 
Table 2

Central Government Expenditure, \% of GDP

\begin{tabular}{|r|r|r|r|r|r|r|r|}
\hline & Switzerland & Germany & \multicolumn{1}{l|}{ Canada } & United States & \multicolumn{1}{l|}{ Spain } & \multicolumn{1}{l|}{ Belgium } & \multicolumn{1}{l|}{ Austria } \\
\hline $\mathbf{2 0 0 5}$ & 11,3 & 14,2 & 16,1 & 19,0 & 17,6 & 29,5 & 34,5 \\
\hline $\mathbf{2 0 1 4}$ & 10,5 & 12,9 & 14,2 & 20,3 & 21,6 & 30,6 & 35,5 \\
\hline
\end{tabular}

Source: Eurostat, World Bank, Kierkegaard (2015)

\subsection{Rationale behind coordination mechanisms in federal budgets}

Macroeconomic theory identifies three leading rationales justifying a federal budget: providing federal public goods, providing macroeconomic stabilization, and providing incentives for convergence. Existing federal states (for instance the US) tend to emphasize the first pillar, accompanied by some degree of counter-cyclical stabilization mechanisms (federal spending on unemployment benefit, for instance, reached its maximum of $1 \%$ of US GDP in 2010 (Kierkegaard, 2015)); adjustment and convergence is usually left to market flexibility, which is not very strong in the EMU (Wolff, 2012). While the provision of "European common goods" is undoubtedly of great importance, it would require further transfers of competences (for example in the military field) and thus involves Treaty change, which is not discussed in this paper. This section therefore develops the rationale behind providing financial incentives to member-states in order to achieve better coordination, convergence and adjustment. As will be seen in the next section, the European Council and the Commission have discussed different rationales for such a mechanism. On the one hand, the European Council seemed to stress the support for reforms which would enable stronger growth, while the European Commission paid more attention to incentives for reforms aiming towards a coordinated macroeconomic adjustment which is required for Monetary Union stability. Stimulating growth, however, does not represent a sufficient rationale for such a system. Either growth-enhancing reforms are effective, or they aren't. If they are, the incentive is already there and it is represented by the strengthened economic performance of the country in the medium term. Elaborating from Bonatti (2014), we identify four key rationales for providing central financing for reforms and coordination. 
a. Catching-up: countries failing to reform their own economic system may be lagging behind in the Euro Area, becoming potentially a liability for all others. Thus, it is justified to provide incentives in the catching-up process.

b. Negative Spillover: introducing certain reforms may provoke severe negative externalities on neighbour countries when such reforms fail to be coordinated; this might be the case, for example, of uncoordinated labour reforms.

c. Coordination added-value: certain policy actions yield higher benefits when they are implemented in a coordinated approach; it is the case, for example, of fiscal stimuli to strengthen demand but also transport and services liberalisation. It is a form of prisoner-dilemma, where countries benefitting less from a liberalisation or a reform would oppose its introduction, but countries benefitting more would not proceed without symmetric implementation.

d. Race-to-the-bottom: when timely coordination is missing, there is a risk of "race to the bottom", which may have high social costs and could undermine support for integration.

Yet, member states falling in the categories above may still find it profitable to enact legislation without the need for the corresponding European financial resources. To justify a system of incentives, a mismatch between costs and benefits of coordination must exist. When costs and benefits, for some reason, don't match the expectations of the political actors, an effective coordination equilibrium is out of reach. Such "coordination failure" constitutes indeed the main rationale for a centralised financial intervention, having the goal of setting in place an appropriate system of incentives aimed at making effective coordination attractive enough for national elites to act. We individuate, in particular, four types of coordination failures which, if not addressed, may prevent the enacting of a reform programme:

a. The costs of introducing the desired reforms (for example, labour market, retirement, judiciary systems, healthcare, education) exceed the "fiscal space" available for a country, given the set of regulations and treaty obligations in place at EU level (type 1);

b. There is a temporal mismatch between costs- concentrated in the short run- and benefits, apparent on the medium and long run (type 2). On the one hand, such a mismatched repartition of costs and benefits reduces the political consensus for reforms, 
undermining the ownership of the reform process; on the other hand, politicians are unwilling to bear the costs of reforms which would benefit their successors;

c. There is a societal mismatch, at least in the short run, between the winners and the losers of a given reform; thus the preservation of social cohesion requires temporary expenditure in social policies (type 3);

d. There are inherited problems and long-lasting legacies in given institutions, regions or sectors (such as diffused regional criminality, or high public debt) the correction of which, solely on the basis of national efforts, demands a constant inflow of resources for protracted periods of time and is not compatible with the smooth functioning of a Monetary Union (type 4).

In these cases it is reasonable to put in place a financial instrument in order to provide adequate incentives for coordination and to support national ownership and implementation of agreed reforms. For incentive costs of the first type (insufficient fiscal space at a domestic level because of international and European commitments on deficit targets), it would be sufficient to engineer a gradual, ad-hoc loosening of the SGP, in order to allow the member state concerned the opportunity to amass the resources needed to implement the agreed reform. This is already in place thanks to the Commission communication on flexibility (COM 12/2015: 10) and only needs to be better linked, through secondary legislation, to CSRs. Addressing costs of types 2 and 3 may require a more complex solution. Mismatches between costs and benefits of reforms imply both real financial costs and political costs determined by the complexity of the construction of consensus towards the agreed reform. The latter often become financial costs as well as governments enact expenditure programmes to support citizens bearing the short-term costs of reforms. Of course, it is a national prerogative to decide whether it is worthier to gain the support of those penalized by a reform by enacting compensative measure or to strengthen its consensus in the rest of the constituency. However, both types of mismatches may hamper states' willingness to reform, which would end-up (in some cases but not in all) in generating negative spillovers across borders. When (1) national inaction is due to such mismatches and when (2) such inaction generates negative spillovers, then the EU is legitimized to set-up forms of financial support. The same reasoning applies to type 4 costs (inherited problems). While purely solidaristic approaches have been attempted in 
the past without much success, conditional forms of financing can provide better outcomes. Such financing can be provided, without Treaty change, by changes in the secondary legislation on the European Strategic Investment Fund (Regulation 1017/2015), the EFSM (regulation No. 407/2010, articles 1 and 3), and the funds accompanying the structural funds of the European Union (Regulation 1303/2013, art. 26). Ad-hoc financing provided through the latter case, however, requires a two-step process. First, as suggested in the Commission's Communication of October 2015 on the reform of the European Semester (COM 600/2015: 6-7), existing funding can be modulated to provide support to CSRs' implementation that fall into their respective domain of action. Second, in view of the 2017 review of the Multiannual Financial Framework secured by the Parliament in 2013 (Regulation 1311/2013 , art. 2), the Commission may propose amendments to existing regulations in order to create an ad-hoc vehicle for the purpose by pooling already committed financing. Finally, financing coming from the eventual introduction of a Financial Transactions Tax may help in replenishing the pool of resources available over time.

\subsection{A joint budgetary procedure}

The abovementioned instruments do not require treaty change, only the amendment of secondary legislation; however, the provision of financial incentives to reform is better delivered through an organized revision of the European Semester process. The idea of a Joint Budgetary Procedure (JBP) was originally proposed by Nicoli (2013) and Dhéret et al. (2013), and has been recently re-framed by Enderlein and Haas (2015). The essential feature of a JBP is to embed the national budgetary process into a European-wide, iterative procedure in which financial and budgetary incentives are so structured as to reward continued compliance. At the core of the JBP is a reformed AGS, which should be reorganized in two parts: Headings requiring Joint Action and Headings requiring Coordinated Action. The first part concerns the creation of special-purpose vehicles to deal with issuespecific concerns by pooling national resources. The second part concerns policy areas normally in the domain of national policy-making, in which the Commission considers there is a need for enhanced coordination of domestic policies. The third part concerns specific policies required in a given country. The procedure behind both headings is to be 
divided in five distinct steps: inception, negotiations, finalisation, implementation and approval.

\subsubsection{Joint Action: pooling finances}

Joint actions would be organised, following the input from the Commission or the European Council, to deal with specific issues requiring pooling of resources. The lack of financial means is, indeed, one of the major limitations of the EMU, which lacks its own budget and is supported only by the 1\% GDP EU budget, significantly lower than other fiscal federations (table 2). In principle, the Commission should use this particular heading of the AGS to stimulate the setting-up of extra funding outside of the Multiannual Financial Framework. As highlighted, among others, by the High Level Group on Own Resources (HLGOR) headed by Mr. Monti, the EMU lacks currently both a Treaty Basis, and political willingness, to implement a full-fledged system of genuine own resources (Monti, 2014). Therefore, the 2016 MFF reform cannot be expected to provide either a boost in the total MFF funding or a strengthening of the European Parliament's capacity of raising resources

It follows that any strengthening of the European Union's capacity of enacting expenditure has to be channelled, for the time being, through intergovernmental decision making. Hence, a standardised format for extra-MFF projects would be of great help in preparing the ground for the establishment of a Euro Area Treasury in the middle of the next decade. Depending on the issue, these might be based on pure inter-governmental agreements or enhanced cooperation. The goal of having a separate heading in the AGS is to provide a comprehensive framework and a common structure for a practice that already exists as a mosaic of unrelated decisions, examples are: the ESM, the EFSI or the extrafunds being gathered to deal with the refugee crisis. By streamlining proposals in this field into the AGS, the Commission would, on the one hand, stimulate the practice of pooling together resources, which might constitute the foundations of a Euro Area Treasury envisioned by 2025; on the other hand, it would informally (but substantially) provide an arena for the involvement of the European Parliament, nowadays excluded by any intergovernmental agreement on special-purpose vehicles. 


\subsubsection{Coordinated Action: streamlining reforms}

The second pillar of a JBP concerns the strengthened coordination of national budgets. Strengthened coordination begins with an appropriate heading of the AGS identifying, by policy area, and (group of) countries, actions requiring enhanced coordination. Following the AGS, the Eurogroup would establish sectoral working groups covering each of the policy areas that are the object of strengthened coordination. Depending on the matter, only some countries may be required to join the working groups. Similarly, the European Parliament, through its existing powers of consultation with national parliaments (art. 13 TSCG), would invite the chairs of the competent committees of each parliament of the Eurozone to create a working group hosted by the EP, to work along the Eurogroup's own ministerial working group in each of the policy areas. The resulting inter-institutional task force would be led by a Commission representative. Each task force would aim to propose concrete actions for each member-state involved in a particular policy area, with the goal of achieving the desired degree of policy coordination. Strictly speaking, this is procedurally different from a process of policy harmonization because it is neither grounded on a legislative document nor requires member-states to abide by the same regulation. Moreover, the task force may propose that member-states adopt a divergent course in certain policy areas in order to achieve a particular coordination objective- it might be the case, for example, of labour policy or public expenditure, where Eurozone-wide objectives are better achieved by a different composition of divergence rather than pure convergence among member states (IMF, 2012). This joint task force would constitute an iterative process of negotiations leading to both a working-group and country-specific, detailed policy documents aimed at informing July's country-specific recommendations. Finalised recommendations would be directed to countries individually, and to working groups of countries, and would require the application of the specific content of the country-specific report in the yearly national budget. Both the working-group and the country-specific policy documents would include expenditure targets for specific areas, for both participating countries as a whole, and individual countries. As a general fiscal rule, the overall expenditure limit agreed within the coordinated Headings should not push the Euro Area as a whole above the 3\% deficit/GDP target; it might, however, lead individual countries to temporarily over-shoot the target, as long as they implement their coordinated Headings in the national budgets as agreed in the Joint Task Force. The overall package of 
actions under the country-specific documents would constitute, for each given country, the coordinated pillar of its yearly budget, presented as a separate heading in national budgetary law; such to be presented annually to the Commission by October 15th in line with the existing European Semester timetable. Overall, coordinated budgetary headings constitute the coordinated budgetary pillar of the monetary union, while budgetary headings not included in the coordination process would constitute the national pillar of the monetary union budget. At the concluding stage, the European Commission, in accordance with the criteria laid down in the SGP, would assess the application of fiscal rules in the overall budgetary law. However, as discussed in the next section, different fiscal rules would apply to the coordinated heading of national draft budgetary laws.

Until there is an enactment of treaty change, member-states retain full sovereignty over their national budgets, as such, incentive mechanisms should be put in place to ensure compliance with the agreed package of measures coordinated through the second pillar of the JBP. Fiscal Rules would continue to characterize the boundaries of fiscal freedom of member states under the JBP; in particular, the overall budget of a country would remain subject to the existing fiscal rules, with particular reference to the 3\% deficit/GDP target and the $0.5 \%$ improvement towards MTO. However, the Commission would have an assessment role in judging that the Coordinated Headings of the national budgetary laws were both in line with what agreed in the Joint Task Forces, and reproduce the recommendations as detailed in the agreed country-specific reports. In such a case, the eventual deficit agreed in the Joint Task Force to finance the Coordinated Headings would not be considered in the computation of the deficit threshold. The 3\% fiscal rule would apply, however, to the coordinated budgets when assessing the Euro Area deficit/GDP ratio as a whole. Suggested originally by the Dutch Finance Minister De Jager in 2011 (Karagiannis and Guidi, 2014), endorsed by Barroso (2011) and by the German Financial Minster Mr. Schäuble (Spiegel, 2012) and by several authors (see, for instance, Enderlain and Haas, 2015) a "European Financial Minister", with powers of veto, would enhance the incentive strategy. Of course, no formal veto powers on national budgets could be envisaged, as it would require a degree of sovereignty transfer not envisioned in the current treaty setting. 
Figure 2

The Joint Budgetary Procedure

The Commission releases

\section{Headings requiring Joint Action}

Special-Purpose Vehicles:

ESM, EFSI, Unemployment Insurance, Refugees

Funds, funds for Contractual Agreements

\section{Headings requiring \\ Coordinated Action}

coordination of reforms, joint

projects, standardization,

National budgetary chapters

with systemic risk

Commission Proposal in the AGS

Commission Proposal

Agreed Upon by the EuroSummit,

with specific, extra-MFF legal

instruments

Joint Task Force negotiations

(Eurogroup \& joint EP + National

Parliaments Groups)

Country-Specific Documents approved

provide funding to:

implemented as Country specific Documents

in a separate Heading of:

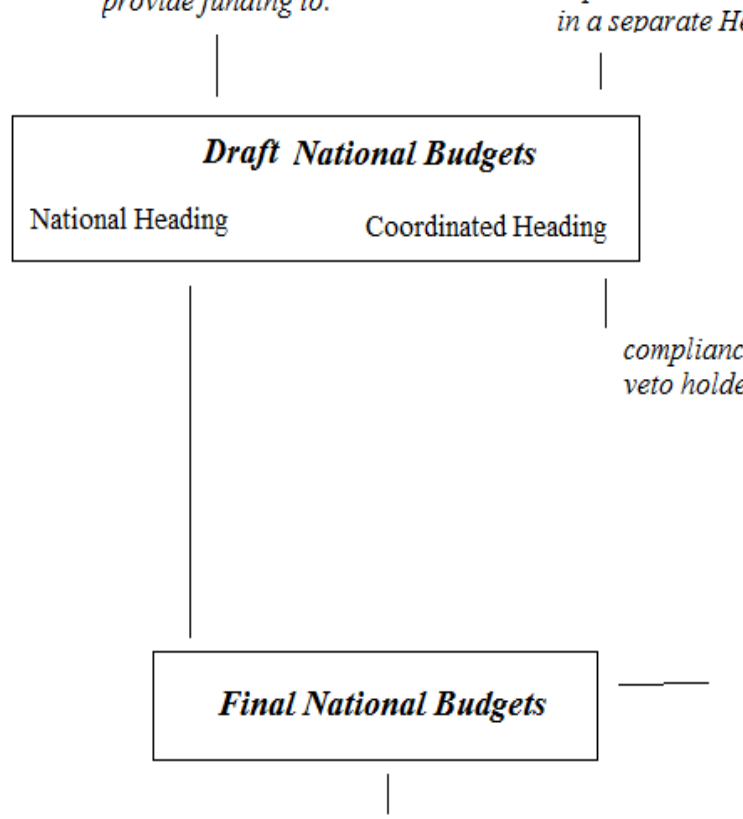

Veto-holder approval for flexibility instrument and eventual funding from special-purpose vehicles

If approved, eventual deficit resulted from policies agreed under this pillar provides flexibility space for the national Headings of the Budget.

Commission Assessment of final National Budgetary Laws according with the EDP and flexibility allowances 
Instead, this authority could apply the veto to flexibility and financial measures adopted under the Coordinated Headings of national budget. This would have no legal consequences and would not require formal legislation: the country subjected to the veto would still be able to approve its national budget including the vetoed measures. However, the veto would prevent the Commission from using either of the two incentivisation instruments presented above: flexibility and contractual financing. Failure in coordination, therefore, would be associated with a high cost for a country, because its overall budgetary position would need further adjustment to comply with the deficit/GDP ratio.

When, by 2025, Treaty change has been accomplished and a Euro Area Treasury established, instruments such as Union Bonds could be emitted to finance parts of the expenditure enacted under the Coordinated Headings. Moreover, the ESM could be used to introduce a modified form of the "red/blue bond proposal" (Depla and Weizsäcker, 2010); pending approval of the veto-holder, debt enacted under the coordinate pillar would enjoy seniority and guarantee from the ESM, while in contrast debt enacted under the national pillar would have neither seniority nor guarantees. This would provide a strong incentive to keep the books balanced in the national pillar, increasing coordination and ensuring both the application of EU fiscal rules, and the strengthening of reciprocal trust.

\section{Conclusions}

The formal and informal strengthening of Economic Governance (and of its master, the European Commission), analysed in the first part of this paper, suffers from two essential limitations: first, it is still not sufficient in providing a permanent setting for the EMU; and second, it lacks the democratic legitimacy to do so. Against this background, scheduled changes to governance, expected to be incrementally introduced in the next ten years, appear insufficient. Given the absence of Treaty Change, not expected before 2025, in the second part of the paper we have put together, elaborating from existing policy proposals, two alternatives to the current and expected setting which would be substantially more efficient. In the absence of Treaty change, no reform can be expected that increases the formal powers of the European Parliament, provides further limitation of budgetary sovereignty, or expands the small federal budget the EU is currently endowed with as MFF. Both proposals, therefore, rely on intergovernmental protocols, inspired by the 
informal agreement behind the first European Semester in 2010 (before its codification in December 2011). Both proposals would enhance Parliamentary scrutiny because they are anchored into the AGS, which is expected to be voted upon by the EP.

The contractual agreements' proposal had been widely discussed in the literature and by policy-makers in the lead up to the December 2014 European Council. Its major strength is its limited range of action and the flexibility that characterizes its functioning. However, it has three major drawbacks. First, its capacity of influencing policy-making is asymmetric; countries with limited need of reforms would be unaffected and would lack incentives to coordination. Second, it would imply "putting a price-tag on reforms" to countries thus creating a precedent in fields for which a case for financing does not exist. Third, the system would not provide a suitable basis for a smooth transition towards a Euro Area Treasury expected for 2025, which is not likely to be anchored into contractualism. Therefore, while a limited contractual agreements scheme might work in fostering reforms in weak countries, it would not provide a suitable basis for smoothing the 10-year long transition towards a common Treasury. The JBP analysed in this paper merges several existing proposals, from the "Euro-Area Commissioner" to the "threefold model of fiscal union". The core element is to allow the Commission, through the AGS, to stimulate member-states, on the one hand, to set up ad-hoc, extra-MFF instruments to deal with specific functions, and, on the other hand, to proceed with strengthened coordination of certain economic policies. This approach differs from the Contractual Agreements' Mechanism, as the JBP is more suited as a transition instrument because it provides better coordination of the overall policies of EMU countries, decreasing divergence in view of the 2025 leap (which, accordingly with the Five Presidents' Report, will be conditional to successful convergence). Moreover, the two pillars of the procedure are designed to evolve, respectively, into a Euro Area budget and into forms of Eurobonds that guarantee enhanced coordination once Treaty change allows for it. Strengthened coordination in the form of a JBP, therefore, is to be preferred to a contractual agreements proposal in view of a smooth transition ahead of 2025.

\footnotetext{
*University of Trento. Email: Francesco.nicoli@,unitn.it.

I In fact, fiscal integration is a condition for the EMU to survive. This can be done explicitly and democratically, or implicitly through monetary backstop. De Grauwe and Ji (2013), Sinn and Wollmerahausen (2012), and Schelkle (2012) argue - from quite different perspectives- that the ECB'OMT and QE policies have achieved precisely this goal.
} 


\section{References}

- Akitoby Bernardin. (eds), 2013, Reassessing the role and modalities of fiscal policy in advanced economies, International Monetary Fund Policy Paper, June 2013.

- Barroso José Manuel, 2011, Speech by President Barroso at the Plenary Assembly of the European Parliament, Strasbourg, October 27th 2011.

- Beblavy Miroslaw and Maselli Ilaria, 2015, 'The Case for an European Unemployment Benefit Scheme', CEPS Commentary, May 19th, 2015.

- Beblavy Miroslaw, Maselli Ilaria and Marconi Gabriele, 2015, A European Unemployment Benefit Scheme: rationale and challenges ahead, CEPS Special Study No. 119, September 2015.

- Bonatti Luigi and Nicoli Francesco, 2014, 'Verso un meccanismo europeo di "accordi contrattuali": partnerships per la crescita e l'occupazione', in Paganetto L. (ed), Revitalizing Anemic Europe: Rapporto del Gruppo dei 20 al Governo Italiano, Eurilink, Roma, XXXX

- $\quad$ Camera dei Deputati, 2014. Atto di Indirizzo, March 7th, 2014.

- $\quad$ Charlemagne (column), 2014. “Your Flexible Friend”. The Economist, March 14th, 2014.

- Christiansen Thomas, 1996, 'A Maturing Bureaucracy? The Role of the Commission in the Policy Process', in Richardson J. (ed), European Union Power and Policy-Making, Routledge, London and New York, 7795.

- Christiansen Thomas, 2001, 'The European Commission: Administration in Turbulent Times', in Richardson, J. (ed) European Union: Power and Policy Making, 2nd Edition, Routledge, London-New York, 95114.

- De Finance Stanislas, 2014. A “traffic-light" approach to the implementation of the 2011-2012 country-specific Recommendations. European Parliament Study, March 2014.

- $\quad$ De Grauwe Paul, 2012, Economics of Monetary Unions, Oxford University Press Oxford.

- De Grauwe Paul and Yuemei Ji, 2013. Fiscal Implications of ECB’s Bond Buying Programme. Vox Policy Portal, June 14, 2013.

- Delpla Jaques and Jacob Von Weizsäcker, 2010. The Blue Bond Proposal, Bruegel Policy Brief, Issue $03 / 2010$

- Deroose, Servaas, Hodson, Dermot and Joost Kuhlmann, 2008. The Broad Economic Policy Guidelines: Before and after the Re-Launch of the Lisbon Strategy. Journal of Common Market Studies, Vol.49, Issue 4.

- Dhéret, Claire, Nicoli, Francesco and Fabian Zuleeg, 2013. The impact of the European Fiscal Union on local autonomies. EPC Report for the Committee of the Regions, June 2013

- Drudi, Francesco, Durré Alain and Francesco Paolo Mongelli, 2012. The Interplay of Economic Reforms and Monetary Policy: The Case of the Eurozone, Journal of Common Market Studies, Vo. 50, Issue 6, pp.881-898

- ECOFIN, 2010. Specifications on the implementation of the Stability and Growth Pact and Guidelines on the format and content of Stability and Convergence Programmes. Consolidated version endorsed by the Council on 7 September 2010.

- $\quad$ Enderlein, Hendrik. and Jörg Haas, 2015. What would a European Financial Minister do? A proposal. Jacques Delors Institute Policy Paper, No.145- October 2015

- European Commission, 2013a. "Towards a Deep and Genuine Economic and Monetary Union: Ex ante coordination of plans for major economic policy reforms". Communication of the Commission, No. $\operatorname{COM}(2013) 166$. final.

- $\quad$ European Commission, 2013b. "Towards a Deep and Genuine Economic and Monetary Union: The introduction of a Convergence and Competitiveness Instrument" Communication of the Commission, No. $\operatorname{COM}(2013)$ 165.Final.

- $\quad$ European Commission, 2015a. "Making the best use of the flexibility within the existing rules of the Stability and Growth Pact", Communication of the Commission, No. COM(2015)12.final.

- European Commission, 2015b "On Steps towards Completing Economic And Monetary Union”, 
Communication of the Commission, No. COM(2015)600.final.

- $\quad$ European Council, 2012. Conclusions of the European Council of 14 December 2012.

- $\quad$ European Council, 2013a. Conclusions of the European Council of 18 December 2014.

- $\quad$ European Council, 2013b. Conclusions of the European Council of 19/20 December 2013.

- $\quad$ European Council, 2013c Conclusions of the European Council of 24/25 October 2013.

- $\quad$ European Council, 2013d Conclusions of the European Council of 28 June 2013.

- $\quad$ European Council, 2014a. Conclusion of the European Council of 20/21 March 2014.

- $\quad$ European Council, 2014b. Conclusions of the European Council of 26/27 June, 2014.

- $\quad$ European Council, 2014c Conclusions of the European Council of 20/21 March 2014.

- $\quad$ European Union, 2012. Final Statement of the Euro Area Summit of 29 June 2012.

- $\quad$ Eyraud Luc and Tao Wu, 2015, Playing by the rules: reforming fiscal governance in Europe, International Monetary Fund Working Paper, No. 15/67, Washington.

- $\quad$ Farage Niegel, 2014, Intervention in the European Parliament Plenary, October 22th, 2014, Strasbourg.

- Hefftler Claudia and Wessels Wolfgang, 2013, The Democratic Legitimacy of the EU Economic Governance and National Parliaments, IAI Working Papers, No 13/2013.

- Hix Simon, 2013, Why the 2014 European Elections Matter: Ten Key Votes in the 2009-2013 European Parliament. European Policy Analysis, No. 15/2013.

- Hix Simon and Høyland Bjorn, 2013, 'Empowerment of the European Parliament', Annual Review of Political Science, XVI: 171-189.

- Hix, Simon and Marsh Michael, 2011, 'Second-order effects plus pan-European political swings: An analysis of European Parliament elections across time'. Electoral Studies, no. 30: 4-15.

- Hix Simon, Noury Abdul and Roland Gérard, 2007, Democratic Politics in the European Parliament, Cambridge University Press, Cambridge/UK.

- Hooghe Lisbeth. And Marks Gary, 2009, 'A postfunctionalist theory of European Integration: from permissive consensus to constraining dissensus', British Journal of Political Science, XXXIX(1): 1-23.

- Karagiannis, Yannis. and Guidi Mattia, 2014, 'Institutional Change and Continuity in the European Union: the Super-Commissioner Saga', Acta Politica, No 49: 174-195.

- Italian Government, 2015. Completing and strengthening the EMU. Italian Contribution to the Five Presidents Report, May 2015.

- Juncker Jean Claude, 2015, Speech by President Juncker at the European Parliament Plenary Session, Strasbourg, October 27th, 2015.

- $\quad$ Kierkegaard Jacob, 2015, Economic Governance Structures in the United States. European Parliament Report, October 2015.

- $\quad$ King, Tom, 1999. The European Commission: administration or government? London: Centre for Policy Studies.

- Kopits Georges and Steven A. Symanky, 1998. Fiscal Policy Rules, International Monetary Fund Occasional Papers, No. 162, Washington.

- $\quad$ Lacombe, Clément and Frédéeric Lemaitre, 2012. Interview with Jens Weidmann. Le Monde, February 25th, 2012.

- Majone, Giandomenico,1997. The regulatory state and its legitimacy problems. Western European Politics, No. 22, Issue 1, pp. 1-24

- Majone Giandomenico, 2014, 'From a Regulatory State to a Democratic Default', Journal of Common Market Studies, LII(6): 1216-1223.

- McDougall Donald (ed), 1977. Report of the Study Group on the Role of Public Finance in European Integration. Brussels, April 1977.

- Monti Mario (ed), 2014. High Level Group on Own Resources: First Assessment Report. Brussels, December 2014.

- Moravcsik Andrew, 2002, 'In defence of the "Democratic Deficit": reassessing legitimacy in the European Union', Journal of Common Market Studies, XL(4): 603-24.

- Mundell Robert, 1960, 'The Monetary Dynamics of International Adjustment Under Fixed and Flexible Exchange Rates', Quarterly Journal of Economics, LXXIV(2): 227-257.

- $\quad$ Mundell Robert, 1961, 'A Theory of Optimal Currency Areas', American Economic Review, LI(4): 657- 
665.

- Nicolaidis Kalypso, 2013, 'European Demoicracy and its crisis', Journal of Common Market Studies, LI(2): 351-369.

- Nicoli Francesco, 2013, Pathways to achieve a Genuine Fiscal Union. EPC Policy Brief, June 2013.

- Nicoli Francesco, 2015, 'Legitimacy, Democracy, and the future of European Integration', in Krieger Tim, Panke Diana and Neumaker Bernhard (eds), Europe's Crisis: the conflict-theoretical perspective. Nomos Publishing, University of Freiburg.

- $\quad$ Nicoli Francesco, 2016a, 'Euroscepticism and the Economic Crisis: evidence from a 108 elections panel study', Journal of Common Market Studies (forthcoming).

- $\quad$ Nicoli Francesco, 2016b, 'From Governance to Government? an analysis of the Commission's Bid to politicise EMU rules', currently in review at Journal of European Integration. Available on SSRN at: http://papers.ssrn.com/sol3/papers.cfm?abstract id=2731760.

- Otjes Simon and Van der Veer Harmen, 2016, 'The Eurozone Crisis and the European Parliament's changing lines of conflict', European Union Politics, January 6, 2016.

- $\quad$ Palmeri, Tara, 2015. The most exclusive dining club in Brussels. Politico, June 18th, 2015

- Pisani-Ferry Jean, Vihriälä Erkki and Wolff Guntram, 2013, 'Options for a Euro Area Fiscal Capacity', Bruegel Policy Contribution, Issue 01/2013.

- $\quad$ Schelkle Waltraud, 2012, 'European fiscal union: from monetary back door to parliamentary main entrance', CESifo Forum, XIII(1): 28-34.

- Schmidt Vivien, 2006, Democracy in Europe: the EU and National Polities, Oxford University Press, Oxford.

- Schulz Martin, 2015, Speech by Martin Schulz, Informal Meeting of the Heads of State and Government. Brussels, February 12th, 2015.

- $\quad$ Sinn Hans-Werner, 2011, 'The ECB’s Stealth Bailout', Vox Policy Portal, June 1, 2011.

- $\quad$ Sinn Hans- Werner, 2014, The Euro Trap: On Bursting Bubbles, Budgets, and Beliefs, Oxford University Press, Oxford.

- Sinn Hans-Werner and Wollmershäuser Timo, 2011, 'Target Loans, Current Account Balances and Capital Flows: The ECB's Rescue Facility', International Tax and Public Finance, XIX(4): 458-508.

- Spiegel Online, 2012, 'New Powers for Brussels: Germany's Schäuble Presents Master Plan for Euro', Spiegel Online, October 16 $6^{\text {th }}, 2012$.

- $\quad$ Spiegel Peter, 2014, 'Renzi leads center-left drive to loosen fiscal rules', Financial Times, June 19th, 2014.

- $\quad$ Terzi Alessio, 2015, No coordination without Representation. Bruegel, October 8th, 2015.

- Tusk Donald, 2016, Draft Decision of the Heads of State or Government, meeting within the European Council, concerning a New Settlement for the United Kingdom within the European Union.

- V Van Rompuy Herman (ed), 2012. Towards a Genuine Monetary Union, Brussels, December 2012

- Werner Pierre (ed), 1970, Report to the Council and the European Commission on the realisation by stages of a Economic and Monetary Union in the Community, Brussels, October 1970.

- Wincott Daniel, 2001, 'Looking Forward or Harking Back? The Commission and the Reform of Governance in the European Union', Journal of Common Market Studies, XXXIX(5): 897-911.

- Wolff Guntram, 2012, ‘A Budget For Europe’s Monetary Union', Bruegel Policy Contribution, Issue 22/2012.

- Zuleeg Fabian, 2015, Can the eurozone's economic governance combine political accountability, legitimacy and effectiveness? EPC Discussion Paper, September 2015.

Legal Acts

- Treaty Establishing the European Stability Mechanism

- Treaty on Stability, Coordination and Governance

- Treaty On the European Union

- Treaty on the Functioning of the European Union

- $\quad$ European Union Regulation 1017/2015

- $\quad$ European Union Regulation 1311/2013 
- $\quad$ European Union Regulation 1303/2013

- $\quad$ European Union Regulation 473/2013

- $\quad$ European Union Regulation 472/2013

- European Union Regulation 1173/2011

- $\quad$ European Union Regulation 1174/2011

- $\quad$ European Union Regulation 1175/2011

- $\quad$ European Union Regulation 1176/2011

- $\quad$ European Union Regulation 1177/2011

- $\quad$ European Union Regulation 407/2010

- $\quad$ European Union Regulation 1966/97

- $\quad$ European Union Regulation 1967/97 